\title{
GEOECOLOGICAL STUDIES ON THE KARSTIC SURFACES OF THE PLANNED PROTECTED AREA IN WESTERN MECSEK, SOUTH HUNGARY
}

\begin{abstract}
GEOEKOLOŠKE RAZISKAVE KRAŠKEGA POVRŠJA NA NAČRTOVANEM ZAŠČITENEM OZEMLJU V ZAHODNEM DELU POGORJA MECSEK NA JUŽNEM MADŽARSKEM
\end{abstract}

EDIT HOYK ${ }^{1}$

\footnotetext{
${ }^{1}$ University of Szeged, Departement of Physical Geography, Szeged, Egyetem u. 2. 6722. P.O. Box 653, HUNGARY.
} 
UDK: 502.7:551.4(439-13)

\section{Edit Hoyk: Geoekološke raziskave kraškega površja na načrtovanem zaščitenem ozemlju v zahodnem} delu pogorja Mecsek na južnem Madžarskem

Na podlagi izsledkov starejših raziskav je bil zahodni del pogorja Mecsek vključen v naravni park Donava Drava. Zato je bilo treba raziskati tudi prsti in rastlinstvo. Raziskave prsti so bile usmerjene predvsem v določanje $\mathrm{pH}$ in merjenje vsebnosti kalcija. To je pomembno za nadaljnje raziskave o vsebnosti težkih kovin v prsti. Vegetacijske raziskave so obsegale vodno bilanco, reakcijo prsti in njihovo kategorizacijo z vidika varstva narave. Posredni človekov vpliv na to kraško ozemlje se kaže v splošnem zniževanju pH. To pa je manjše v vrtačah, ker imajo te prsti razmeroma visoko vsebnost kalcija. Pravilnost zaščite tega kraškega območja opravičujejo rastlinske združbe z visokim deležem zaščitenih vrst med spremljajočimi vrstami. Raziskave potrjujejo, da je nujno ohraniti sedanje stanje, za kar pa je potrebna ustrezna zaščita.

Ključne besede: kras, geoekologija, vrtača, prst, rastje, zaščita narave, Mecsek, Madžarska.

\section{Abstarct}

UDC: 502.7:551.4(439-13)

Edit Hoyk: Geoecological studies on the karstic surfaces of the planned Protected Area in Western Mecsek, South Hungary

Earlier studies on the karst in Western Mecsek have already shown that this area is worth protection due to its quite well preserved natural state. In consequence, declaring the karstic territory with its wider environment as a protected area is being considered in the Danube-Drava Natural Park. In order to prove the almost untouched natural state of an area good starting point is to examine its soil and flora. Soil studies focus on determining the $\mathrm{pH}$, detecting any tendency of a shift towards lower $\mathrm{pH}$ values and on examining the carbonate content. In the future measurements to check the heavy metal content that are especially suitable for showing the levels of anthropogenic contamination will be added to these studies. Investigations on the flora based on the examination of water balance, soil reaction and determination of the rank according to the categories of nature conservation value offer a support to the claim of being protected. The results show that indirect anthropogenic effects can be detected by the $\mathrm{pH}$ shift towards lower values, but the same tendency of turning acidic is less characteristic in dolines which are the most sensitive points of karstic fields. However, the relatively high carbonate content favours the resistance against felling $\mathrm{pH}$ values. Examining the vegetation, and paying special attention to the ranking into nature conservation categories, a significantly high ratio of association - forming and accompanying species and the presence of protected species in relatively high numbers can be seen that proves the nature conserving feature of the territory. On the basis of the investigations carried out the maintenance of the present state of the territory is a desirable objective and in order to realize it the protection of the area is absolutely justified.

Key words: Mecsek Mountains, karst, dolina, geoecology, soil, vegetation, protected area, protection. 
The Mecsek Mountains are the southernmost mountain range of Hungary. There are three adjoining karstic areas in its western part: near the villages of Abaliget and Orfü, and in the Melegmány Valley. These three areas are part of the Western Mecsek Mountains Protected Area proposed by the Danube-Dráva National Park. The southern part of this area is covered by sandstone, so that is not part of our project (Fig. 1).

The intensive karstic processes began in the pleistocene and have been continuous till today (LOVÁSZ 1977), which can be proved by the high number of dolinas which are still forming.

There have been geoecological examinations of the area near Orfü, which are now extended to the Abaliget and Melegmany areas.

The goal of the examinations, which concentrate on the soils and the flora, is to prove that these areas are worth protecting. There had been similar research in the Aggtelek karstic region and in the Bükk Mountains, too (KEVEINÉ 1983).

The pedological examinations were carried out in laboratory conditions. The vegetation, however, was inspected on site.

The pedological examinations consisted of the analysis of $\mathrm{pH}$-value, carbonate-, and heavy metal-content.

The $p H$-value of the soil is acidic, the average value is 5-6. The graph (Fig. 2) shows that the average $\mathrm{pH}$ in the Melegmány area is a little bit higher, and there are more values around neutral. This can be explained by the higher carbonate content of the soil here. The acidic $\mathrm{pH}$ is natural, because these soil types (the main type of soil is brown forest soil with clay washed in) usually have such a pH value (STEFANOVITS 1975). There is, however, a considerable difference between the

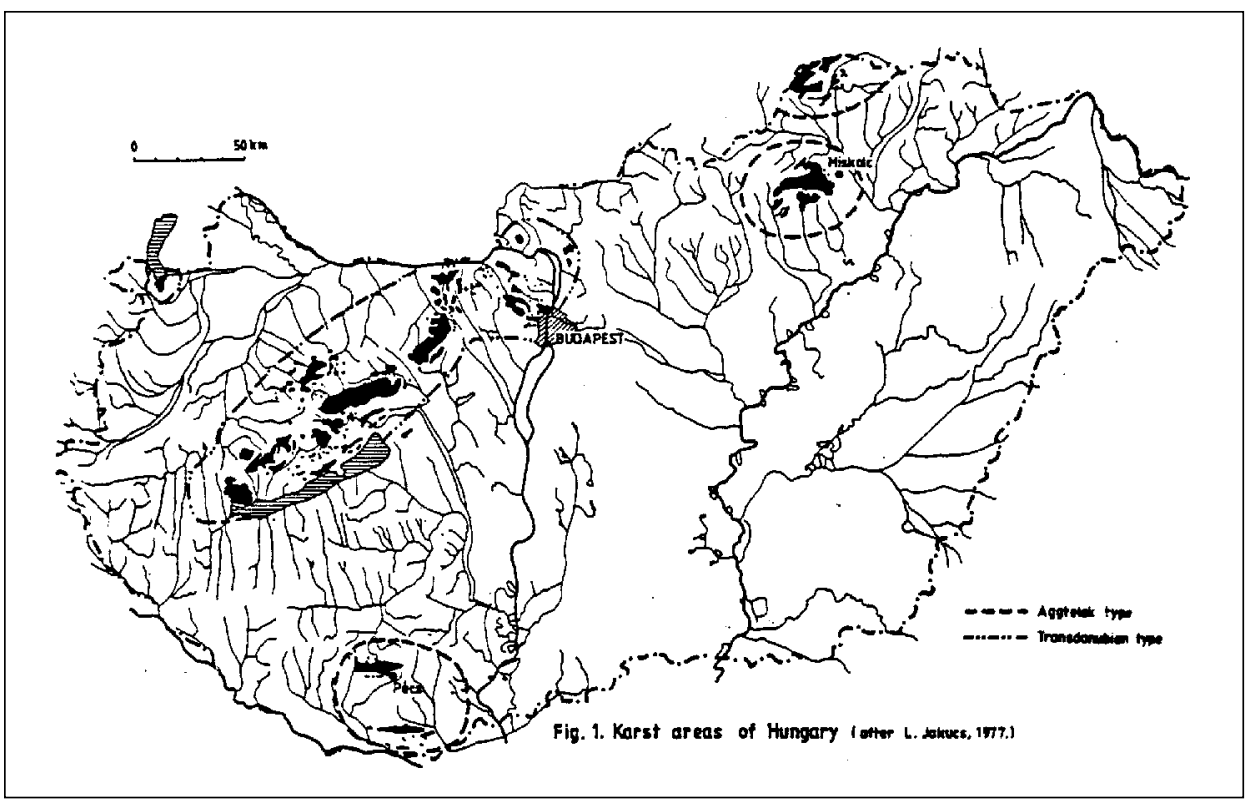

Fig. 1: Karst areas of Hungary. 


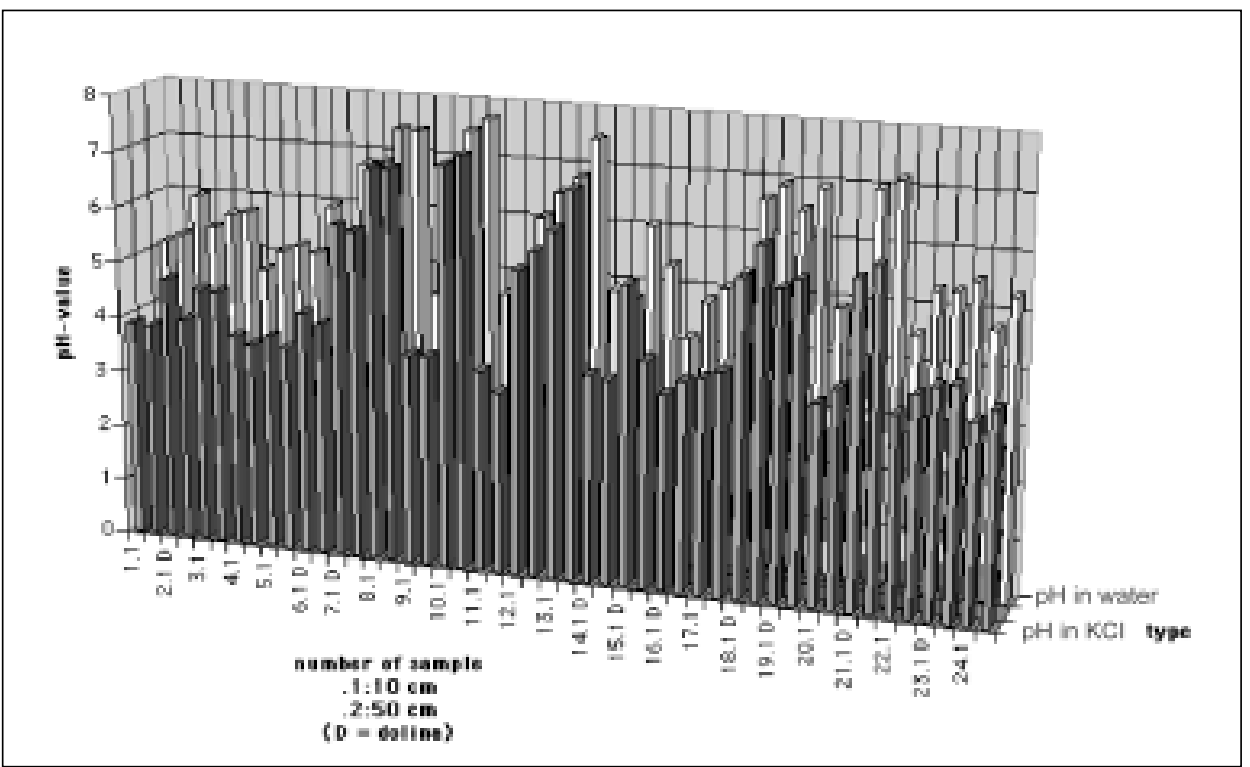

Fig. 2: The pH of soils.

$\mathrm{pH}$ in water and in potassium chloride. When this difference is more than 0.5 , the soil is acidifying. There were only two samples that did not show a difference higher than 0.5 , both near the surface and at a depth of $50 \mathrm{~cm}$. The differences in the other samples were around 1.2. It can clearly be seen that there is a tendency towards acidification, especially in the Orfü area. The acidification may be caused by some human activity, mainly in the industrial areas of the city of Pécs. The acidification is caused by indirect effects which can be traced by comparing the acidity of the samples collected from just under the surface and ones from a depth of $50 \mathrm{~cm}$. The $\mathrm{pH}$ of samples taken from deeper sections is usually higher because acidification is more intensive closer to the surface.

10 of the 24 soil and vegetation samples were collected from dolinas and the rest from plateaus between dolinas and from valleys.

If we compare the $\mathrm{pH}$ of soil samples from dolinas and the ones from plateaus, it can be seen that the $\mathrm{pH}$ of the samples from dolinas is higher. This led to the conclusion that dolinas are more protected against acidification, which makes them especially important.

The carbonate content of the soils is low (Table 1), which is not surprising with karstic types. There are some samples which have no signs of carbonate in them at all. In the samples, however, in which the difference between the $\mathrm{pH}$ in water and in potassium chloride is below 0.5 , we have detected high carbonate content. It proves the considerable buffer effect of carbonate content, so in these cases carbonate content decreases the intensity of acidification. One of the two samples was collected from a watercourse and the other next to the tufa steps of the Melegmány Valley (samples 8 and 10). 
Edit Hoyk: Geoecological studies on the karstic surfaces of the planned Protected Area in Western Mecsek, South Hungary

Table 1: The carbonate - content of karstic soils in Western Mecsek (\%).

1: $10 \mathrm{~cm}$ depth

$12: 50 \mathrm{~cm}$ depth

\begin{tabular}{|c|c|}
\hline number of sample & carbonate-content \\
\hline $1 / 1$ & 0 \\
\hline $1 / 2$ & 0 \\
\hline $2 / 1$ & 0,106725 \\
\hline $2 / 2$ & 0,04269 \\
\hline $3 / 1$ & 0 \\
\hline $3 / 2$ & 0 \\
\hline $4 / 1$ & 0 \\
\hline $4 / 2$ & 0 \\
\hline $5 / 1$ & 0,17076 \\
\hline $5 / 2$ & 0,064035 \\
\hline $6 / 1$ & 0 \\
\hline $6 / 2$ & 0,04269 \\
\hline $7 / 1$ & 0 \\
\hline $7 / 2$ & 0 \\
\hline $8 / 1$ & 4,6959 \\
\hline $8 / 2$ & 15,7953 \\
\hline $9 / 1$ & 0,08538 \\
\hline $9 / 2$ & 0,12807 \\
\hline $10 / 1$ & 49,5204 \\
\hline $10 / 2$ & 34,152 \\
\hline $11 / 1$ & 0 \\
\hline $11 / 2$ & 0,064035 \\
\hline $12 / 1$ & 0 \\
\hline $12 / 2$ & 0 \\
\hline $13 / 1$ & 0,106725 \\
\hline $13 / 2$ & 0,04269 \\
\hline $14 / 1$ & 0,12807 \\
\hline $14 / 2$ & 0,04269 \\
\hline $15 / 1$ & 0 \\
\hline $15 / 2$ & 0 \\
\hline $16 / 1$ & 0 \\
\hline $16 / 2$ & 0,021345 \\
\hline $17 / 1$ & 0,08538 \\
\hline $17 / 2$ & 0,04269 \\
\hline $18 / 1$ & 0,08538 \\
\hline $18 / 2$ & 0,04269 \\
\hline $19 / 1$ & 0,08538 \\
\hline $19 / 2$ & 0,04269 \\
\hline $20 / 1$ & 0,064035 \\
\hline $20 / 2$ & 0,08538 \\
\hline $21 / 1$ & 0,08538 \\
\hline $21 / 2$ & 0,08538 \\
\hline $22 / 1$ & 0,021345 \\
\hline $22 / 2$ & 0 \\
\hline $23 / 1$ & 0,021345 \\
\hline $23 / 2$ & 0,04269 \\
\hline $24 / 1$ & 0,04269 \\
\hline $24 / 2$ & 0 \\
\hline
\end{tabular}


Table 2: The heavy metal-content of karstic soils in Western Mecsek (ppm).

$11: 10 \mathrm{~cm}$ depth

12: $50 \mathrm{~cm}$ depth

\begin{tabular}{|c|c|c|c|c|c|c|c|c|}
\hline $\begin{array}{l}\text { Nr. of } \\
\text { sample }\end{array}$ & $\mathbf{P b}$ & $\mathrm{Ni}$ & Co & $\mathrm{Cu}$ & $\mathrm{Fe}$ & Mn & $\mathrm{Cd}$ & $\mathrm{Cr}$ \\
\hline $1 / 1$ & 26 & 34 & 17 & 12 & 28850 & 761,5 & 0,3 & 19,5 \\
\hline $1 / 2$ & 21,5 & 39,5 & 12 & 14,5 & 32450 & 667,5 & 0,05 & 20,5 \\
\hline $2 / 1$ & 25 & 35 & 16 & 13 & 29000 & 778,5 & 0,3 & 21 \\
\hline $2 / 2$ & 24 & 36 & 13 & 13 & 28050 & 718 & 0,1 & 20 \\
\hline $3 / 1$ & 26 & 44,5 & 12 & 17 & 36400 & 599 & 0,6 & 27 \\
\hline $3 / 2$ & 25 & 58 & 16 & 23 & 42500 & 841,5 & 0,5 & 29,5 \\
\hline $4 / 1$ & 22.5 & 33 & 14 & 10,5 & 27500 & 572,5 & 0,55 & 18 \\
\hline $4 / 2$ & 19,5 & 40,5 & 15 & 17,5 & 34650 & 532,5 & 0,45 & 20 \\
\hline $5 / 1$ & 22.5 & 35,5 & 9,5 & 13 & 28900 & 448 & 0,2 & 20,5 \\
\hline $5 / 2$ & 17,5 & 42 & 13,5 & 18 & 32600 & 558 & 0,2 & 20,5 \\
\hline $6 / 1$ & 24,5 & 41,5 & 13 & 13,5 & 29000 & 1054 & 0,5 & 20,5 \\
\hline $6 / 2$ & 21,5 & 40,5 & 15,5 & 14 & 29500 & 260,5 & 0,5 & 19 \\
\hline $7 / 1$ & 22.5 & 43 & 11,5 & 17 & 30400 & 1100 & 0,35 & 23,5 \\
\hline $7 / 2$ & 20 & 45,5 & 13 & 19 & 32650 & 875,5 & 0,65 & 21,5 \\
\hline $8 / 1$ & 42 & 49 & 16,5 & 21 & 27550 & 1525 & 1,45 & 25,5 \\
\hline $8 / 2$ & 36,5 & 46 & 13 & 21,5 & 24400 & 1397,5 & 1,5 & 23,5 \\
\hline $9 / 1$ & 30.5 & 36,5 & 14 & 17,5 & 32350 & 1152 & 0,2 & 22 \\
\hline $9 / 2$ & 24 & 43,5 & 21 & 23,5 & 37200 & 1042,5 & 0,7 & 21 \\
\hline $10 / 1$ & 38,5 & 47 & 11,5 & 12,5 & 18450 & 604,5 & 3,35 & 18,5 \\
\hline $10 / 2$ & 38,5 & 48 & 18,5 & 10,5 & 16200 & 224 & 3 & 17 \\
\hline $11 / 1$ & 16,5 & 29 & 9 & 12 & 23550 & 323,5 & 0,3 & 18,5 \\
\hline $11 / 2$ & 20 & 40,5 & 12,5 & 14,5 & 28700 & 772,5 & 0,35 & 18,5 \\
\hline $12 / 1$ & $35 \multimap$ & 52,5 & 14 & 17,5 & 24400 & 948,5 & 0,95 & 32 \\
\hline $12 / 2$ & 30 & 54,5 & 18,5 & 17 & 37450 & 770,5 & 1,15 & 30 \\
\hline $13 / 1$ & 23 & 36 & 12 & 14 & 28650 & 704 & 0,35 & 23 \\
\hline $13 / 2$ & 20 & 41 & 15 & 13,5 & 27450 & 1071 & 0,65 & 20 \\
\hline
\end{tabular}




\begin{tabular}{|c|c|c|c|c|c|c|c|c|}
\hline $\begin{array}{l}\mathrm{Nr} . \quad \text { of } \\
\text { sample }\end{array}$ & $\mathrm{Pb}$ & $\mathrm{Ni}$ & Co & $\overline{\mathrm{Cu}}$ & $\mathrm{Fe}$ & Mn & Cd & $\mathrm{Cr}$ \\
\hline $14 / 1$ & 23.5 & 35,5 & 12,5 & 13 & 30200 & 696 & 0,15 & 20 \\
\hline $14 / 2$ & 20 & 44,5 & 15,5 & 19 & 35850 & 575 & 0,35 & 22 \\
\hline $15 / 1$ & 26.5 & 38,5 & 12 & 12 & 27150 & 1395 & 0,55 & 20 \\
\hline $15 / 2$ & 23.5 & 36,5 & 11 & 12,5 & 28700 & 1108,5 & 0,15 & 19 \\
\hline $16 / 1$ & 17.5 & 29 & 10 & 10 & 24800 & 579 & 0,1 & 17,5 \\
\hline $16 / 2$ & 18 & 34 & 11,5 & 12,5 & 26350 & 722 & 0,55 & 16 \\
\hline $17 / 1$ & 28 & 33 & 17 & 10 & 28000 & 810,5 & 1,05 & 19 \\
\hline $17 / 2$ & 26,5 & 36 & 20,5 & 12,5 & 29800 & 883,5 & 0,85 & 18 \\
\hline $18 / 1$ & 32 & 54 & 17 & 20 & 39650 & 1242,5 & 1,05 & 29 \\
\hline $18 / 2$ & 28.5 & 63 & 19,5 & 22 & 40650 & 889,5 & 1,2 & 27,5 \\
\hline $19 / 1$ & 23 & 52,5 & 15 & 19,5 & 37850 & 713,5 & 0,7 & 26 \\
\hline $19 / 2$ & 23.5 & 49,5 & 16 & 19 & 36600 & 577 & 0,7 & 22,5 \\
\hline $20 / 1$ & 21,5 & 32,5 & 13,5 & 9,5 & 25850 & 649,5 & 0,1 & 18,5 \\
\hline $20 / 2$ & 21,5 & 46,5 & 19 & 15 & 32900 & 803 & 0,8 & 20,5 \\
\hline $21 / 1$ & 23 & 38 & 11 & 16 & 28100 & 1122,5 & 0,3 & 24 \\
\hline $21 / 2$ & 19 & 31,5 & 10 & 10,5 & 22650 & 698,5 & 0 & 17 \\
\hline $22 / 1$ & 25,5 & 38,5 & 19 & 13,5 & 31000 & 704,5 & 0,35 & 20 \\
\hline $22 / 2$ & 20,5 & 59,5 & 14,5 & 25 & 39850 & 628 & 0,85 & 26 \\
\hline $23 / 1$ & 25,5 & 34,5 & 14,5 & 10,5 & 26700 & 950,5 & 0,25 & 18 \\
\hline $23 / 2$ & 19,5 & 41 & 18 & 15,5 & 31100 & 812,5 & 0,85 & 18,5 \\
\hline $24 / 1$ & 22,5 & 34 & 11,5 & 9,5 & 26700 & 474 & 0,15 & 19 \\
\hline $24 / 2$ & 23 & 52,5 & 18 & 19 & 35500 & 620 & 0,5 & 22 \\
\hline average & 24,6 & 41,8 & 14,4 & 15,3 & 30307 & 790,8 & 0,64 & 21,4 \\
\hline $\begin{array}{l}\text { limit } \\
\text { values of } \\
\text { pollution } \\
\text { (plan in } \\
\text { Hungary) }\end{array}$ & 70 & 50 & 50 & 100 & $\begin{array}{l}\text { (no } \\
\text { data) }\end{array}$ & 1100 & 1 & 100 \\
\hline
\end{tabular}




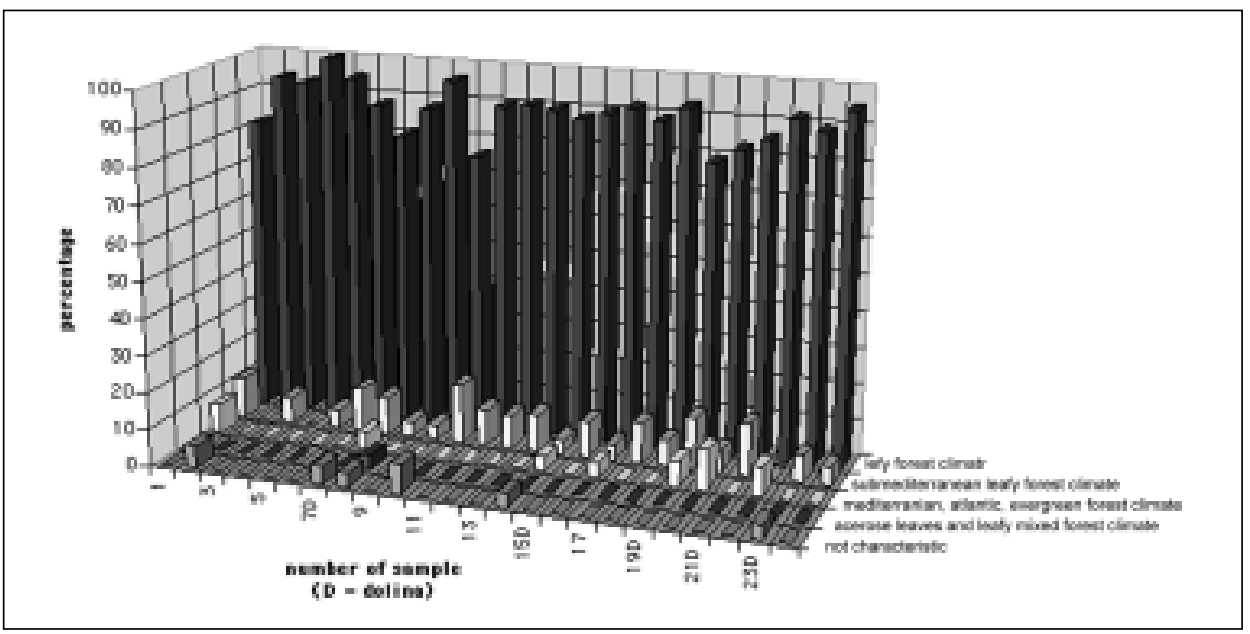

Fig. 3: Categories of T-value (temperature).

The heavy metal tests were carried out with aqua regia and atomic absorption spectrophotometer. $\mathrm{Ni}, \mathrm{Co}, \mathrm{Fe}, \mathrm{Mn}, \mathrm{Cr}, \mathrm{Cu}, \mathrm{Pb}, \mathrm{Cd}$ were tested. The low quantity of these elements (Table 2) implies that the pollution from human sources is low, which proves the existence of natural conditions in the area.

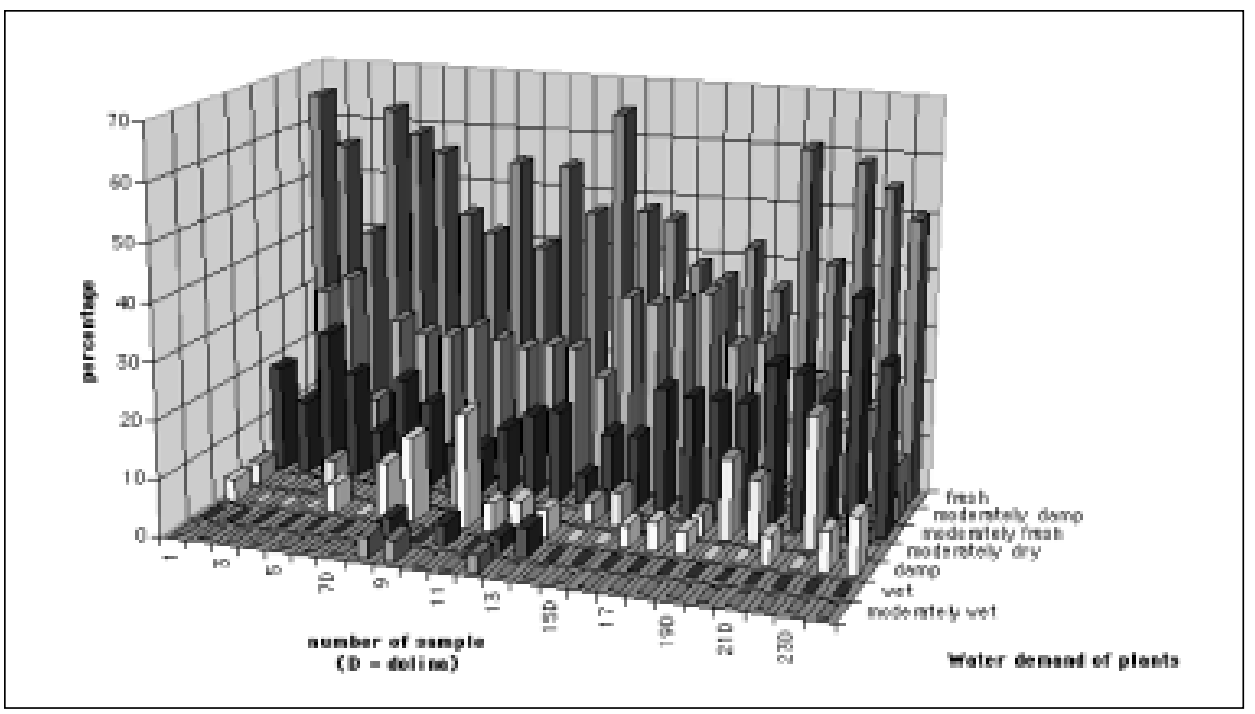

Fig. 4: Categories of W-values (water balance). 


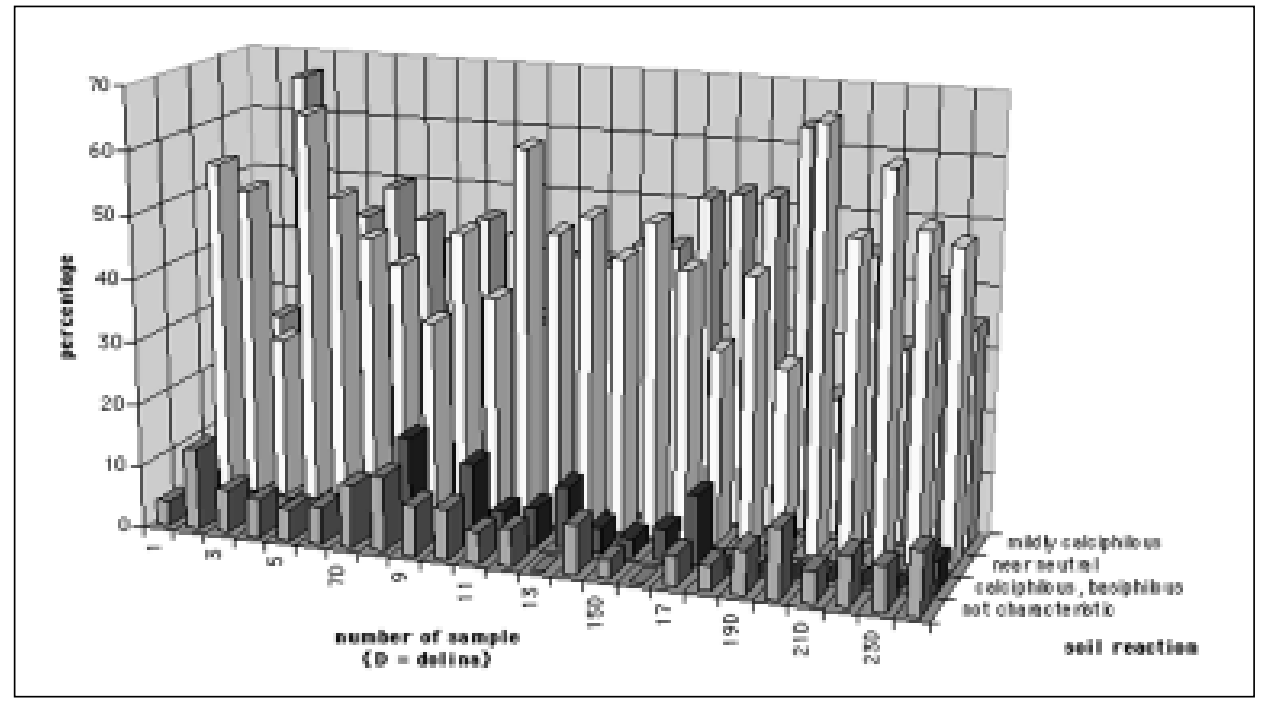

Fig. 5: Categories of R-value (soil reaction).

Vegetation was examined with the help of ecological indexes, considering temperature (T-values), water-balance (W-values), soil reaction (R-values) and nature conservation categories (TVK-values).

Considering the temperature (Fig. 3), most of the plants (80-100\%) indicate a leafy forest climate which is combined with submediterranean leafy forest climate - which refers to the typical vegetation in the Mecsek Mountains - and Atlantic evergreen forest climate. Plus in the above-mentioned watercourse which is a ravine forest, there are some plants that indicate coniferous wood and leafy mixed forest.

Looking at the graph showing water balance (Fig. 4), one can see that most of the plants indicate moderately fresh, fresh, and moderately damp conditions. These values are caused by the fact that these areas are covered by forests. The samples which have a higher number of plants that relate to wet and damp conditions were collected by springs, streams and the tufa steps of the Melegmány Valley. Species that represent moderately dry conditions can be found in the areas where there are several relatively open oak associations.

On the basis of soil reaction (Fig. 5), species that indicate moderately calciphilous and neutral circumstances are a majority. Plants referring to calciphilous and basic conditions can be found mostly in samples which showed a high value of carbonate-content.

The graph showing the nature conservation values (Fig. 6) reveals that most of the species present refer to natural circumstances (accompanying, associated, protected). The proportion of plants that signal degradation (weeds) rarely exceeds $10 \%$. These latter samples were either collected near tourist-paths under heavy usage or close to the Orfü-Pécs highway. The test point near the highway (sample 8) shows well enough how human activity can degrade precious natural areas. 


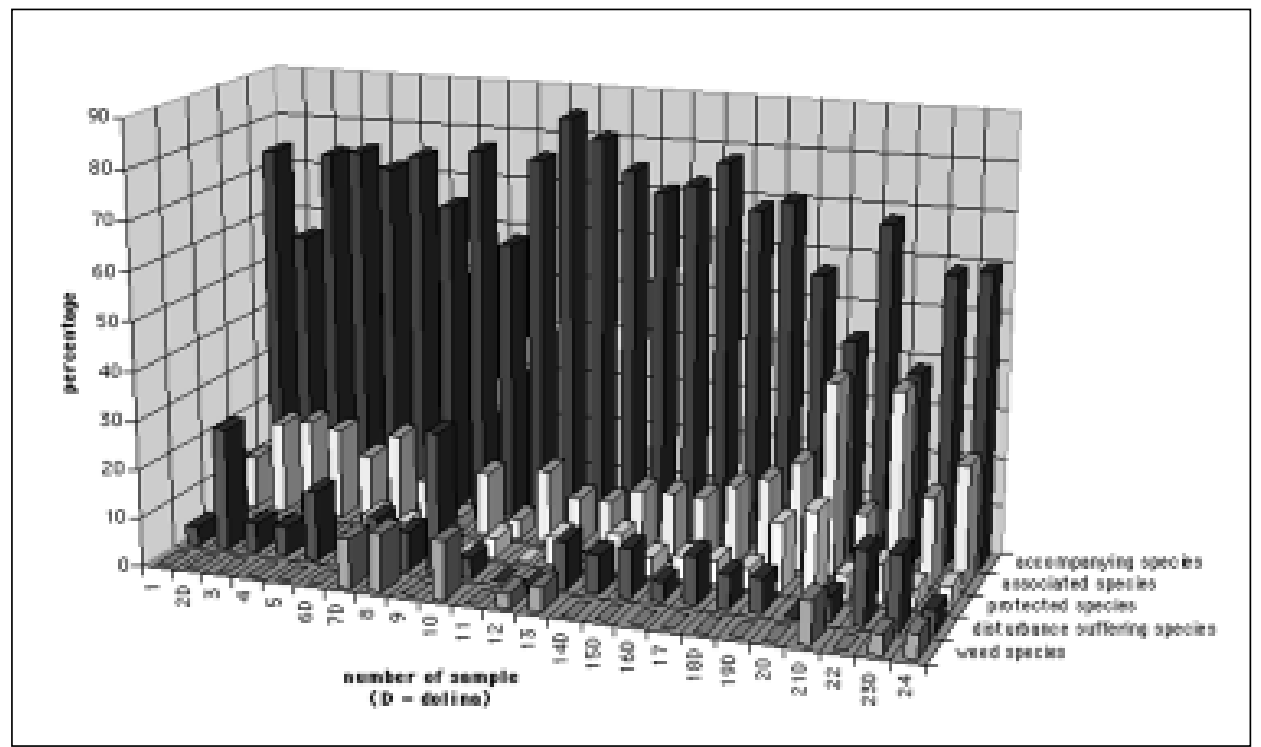

Fig. 6: Categories of TVK-values (nature conservation value).

This is the forementioned watercourse with a ravine forest containing several protected species. The high proportion of weeds here is put down to the interfering effect of the nearby highway.

The samples from the dolinas reveal that they host a larger variety of species. There are more plants that endure shadow because of the steep sides of these karstic forms. The graph showing the preservation categories reveals that there is a tendency that the proportion of protected species is higher in the dolinas than in other areas. It shows how important they are from the point of view of nature preservation. Dolinas are one of the most sensitive places of the karstic surfaces as, like swallets, they are points where pollution can enter the karstic system. Therefore it is good that the dolinas of all three examined areas are free from human interference, which supports the idea of declaring these areas protected.

\section{CONCLUSIONS}

The goal of our pedological and vegetation examinations carried out in the Western Mecsek karstic area is to support the efforts to declare these areas protected.

The analysis of the carbonate and heavy metal-content, and the $\mathrm{pH}$ have shown that there are harmful anthropogenic influence in the area, but it is only an indirect effect which manifests itself in falling $\mathrm{pH}$ values.

Ecological indexes also show that this part of the Mecsek Mountains is still in a natural condition, which justifies the claim to make this area a natural preserve. On the basis of the comparisons of samples from dolinas and other features, it must be noted that dolinas are the most valuable places 
of the three karstic areas examined. The $\mathrm{pH}$ of the soils of the dolinas is close to the values of the prevailing soil type (brown forest soil with clay washed in), whereas the $\mathrm{pH}$ of samples from other places is lower. The analysis of the vegetation also showed that dolinas are in a natural condition to a greater extent, because they host a larger number of protected species.

A karstic area is a vulnerable natural system, that reacts with great sensitivity to antropogenic influences, so it requires increased protection. Particular stress must be layed on dolinas, which are depositaries of the original vegetation and soil. Because of their importance, they are being surveyed and enumerated at present.

The first step to preserve the condition of this area is to declare it protected. In the framework of general protection, dolinas should be more strictly protected. The declaration of protection would not only mean the creation of a new nature reserve but could also have a favourable effect in the wider surroundings because the comprehensive karstic system is quite far-reaching.

\section{REFERENCES}

Horváth Adolf Olivér (1972): Die Vegetation des Mecsekgebirges und seiner Umgebung Akadémiai Kiadó, Bp. 1972.

Keveiné Bárány Ilona (1983): Some data about the composition of flora in karst dolinas. In: Acta

Universitatis Szegediensis. Acta Geographica. Tomus XXIII. Szeged. Pp. 179-187.

Lovász György (1977): Baranya megye természeti földrajza Pécs, 1977. Pp. 62-68.

Morschhauser Tamás (1995): A Mecsek erdőtársulásai Pécs, 1995. P. 17.

Simon T. Tibor (1992): A magyarországi edényes flóra határozója. Harasztok és virágos növények.

Tankönyvkiadó, Bp. 1992. Pp. 789-874.

Stefanovits Pál (1975): Talajtan Mezőgazdasági Kiadó, Bp. 1975. Pp. 55-59.

\section{GEOEKOLOŠKE RAZISKAVE KRAŠKEGA POVRŠA NA NAČRTOVANEM ZAŠČITENEM OZEMLJU V ZAHODNEM DELU POGORJA MECSEK NA JUŽNEM MADŽARSKEM}

\section{Povzetek}

Na podlagi izsledkov starejših raziskav zahodnega dela pogorja Mecsek na južnem Madžarskem, ki so pokazale na dobro ohranjeno naravno stanje, je bilo ozemlje vključeno v naravni park Donava - Drava. Da bi pa to res dokazali, so se za najboljšo osnovo izkazale raziskave prsti in rastlinstva.

Raziskave prsti so bile usmerjene predvsem v določanje $\mathrm{pH}$ in merjenje vsebnosti kalcija. Rezultati meritev pH kažejo tendenco proti nižjim vrednostim. Za bodočnost načrtujemo raziskave vsebnosti težkih kovin v prsti, kar je posebno primerno za ugotavljanje nivoja onesnaževanja, ki ga povzroča človek.

Vegetacijske raziskave so obsegale vodno bilanco, reakcijo prsti in njihovo kategorizacijo z vidika varstva narave. Posredni človekov vpliv na to kraško ozemlje se kaže v splošnem zniževanju pH. To pa je manj značilno za vrtače kot najobčutljivejša mesta kraškega površja. Razmeroma visoka vsebnost kalcija je vzrok njihove odpornosti proti zniževanju pH. Pravilnost zaščite tega 
kraškega območja opravičujejo rastlinske združbe, kategorizirane z vidika ohranjanja narave, ki imajo visok delež zaščitenih vrst med osnovnimi in spremljajočimi vrstami. Raziskave potrjujejo, da je nujno ohraniti sedanje stanje, za kar pa je potrebna ustrezna zaščita. 